\title{
Transactions
}

Cite this: Dalton Trans., 2011, 40, 301

wWW.rsc.org/dalton

PAPER

\section{Rhodium complexes bearing tetradentate diamine-bis(phenolate) ligands $\dagger$}

\author{
Xiang Y. Liu, ${ }^{a}$ Kapil S. Lokare, ${ }^{* b}$ Somesh K. Ganesh, ${ }^{a}$ Jason M. Gonzales, ${ }^{c}$ Jonas Oxgaard, ${ }^{c}$ \\ William A. Goddard III ${ }^{* c}$ and Roy A. Periana*b
}

Received 11th August 2010, Accepted 20th September 2010
DOI: 10.1039/c0dt00997k

Using tetradentate, dianionic ligands, several new rhodium complexes have been prepared. Some of these diamine-bis(phenolate) compounds, are active for $\mathrm{C}-\mathrm{H}$ activation of benzene. These complexes are air and thermally stable. All four complexes were characterized by X-ray diffraction.

\section{Introduction}

First reported in $2000,{ }^{1}$ the family of trans- $\left(\kappa^{2} \text {-acac-O,O }\right)_{2} \operatorname{Ir}(\mathrm{R})(\mathrm{L})$ (acac $=$ acetylacetonato, $\mathrm{R}=$ hydrocarbyl, $\mathrm{L}=$ dative ligand) $\mathrm{O}$ donor complexes have been shown to be capable of activating $\mathrm{C}-$ $\mathrm{H}$ bonds and catalyze the selective, anti-Markovnikov hydroarylation of unactivated olefins with arenes. ${ }^{2}$ These complexes are relatively simple to synthesize and remarkably, likely due to unique properties imparted by O-donor ligands, solutions are thermally stable to air and basic as well as acidic media. Mechanistic studies show that these trans bis-acac-O,O Ir(III) complexes are catalyst precursors and that the active catalysts are generated by loss of $\mathrm{L}$, followed by rate determining trans to cis isomerization to generate coordinatively unsaturated, five-coordinate pseudo square pyramidal complexes with the four O's of the two acac$\mathrm{O}, \mathrm{O}$ ligands in a meridional geometry that places the $\mathrm{R}$ group cis to an open site. ${ }^{3}$ In an effort to design more active catalysts with similar reactivity and stability we sought to explore related metal complexes with tetradentate O-donor ligands that were already locked into meridional geometry. Recently, tetradentate diaminebis(phenols) $\left\{\mathrm{NN}^{\prime} \mathrm{O}_{2}\right\}$ that enforce a meridional geometry with $\mathrm{Ti}$ and $\mathrm{Zr}$ have emerged as alternative ligands in developing new catalysts for polymerization of $\alpha$-olefins ${ }^{4}$ and as sulfoxidation catalysts with $\mathrm{V}^{5}$ In order to test whether replacing the bis-acac$\mathrm{O}, \mathrm{O}$ motifs with these ligand could lead to more efficient $\mathrm{C}-\mathrm{H}$ activation and olefin arylation chemistry we synthesized several new rhodium complexes, $\mathrm{Rh}\left(\mathrm{NN}^{\prime} \mathrm{O}_{2}\right)(\mathrm{R})(\mathrm{L})$. In this contribution we report the synthesis, structure, and reactivity of these new complexes towards arenes.

${ }^{a}$ Loker Hydrocarbon Institute, Department of Chemistry, University of Southern California, Los Angeles, California, USA, 90089

${ }^{b}$ The Scripps Research Institute, Scripps Florida, Jupiter, Florida, USA, 33458. E-mail: rperiana@scripps.edu; Fax: 1-561-228-3064; Tel: 1-561228-2457

${ }^{c}$ Materials and Process Simulation Center, California Institute of Technology, Pasadena, California, USA, 91125.E-mail: wag@wag.caltech.edu $\dagger$ Electronic supplementary information (ESI) available: Additional data. CCDC reference numbers 788725-788728. For ESI and crystallographic data in CIF or other electronic format see DOI: 10.1039/c0dt00997k

\section{Results and discussion}

The ligands $\mathrm{H}_{2} \mathrm{~N}^{\mathrm{py}} \mathrm{N}^{\prime} \mathrm{O}_{2}{ }^{\mathrm{tBu}}$ (1), $\mathrm{H}_{2} \mathrm{~N}^{\mathrm{NMe} 2} \mathrm{~N}^{\prime} \mathrm{O}_{2}{ }^{\mathrm{Me}}$ (1) $)$, and $\mathrm{H}_{2} \mathrm{~N}^{\text {py }} \mathrm{N}^{\prime} \mathrm{O}_{2}{ }^{\mathrm{Me}}$ (1c) were synthesized in a single-step Mannich condensation reaction using the general procedure developed by Kol and coworkers. ${ }^{6}$ The reaction of $\mathrm{H}_{2} \mathrm{NN}^{\prime} \mathrm{O}_{2}$ ligands with the commercially available $\mathrm{RhCl}_{3} \cdot\left(\mathrm{H}_{2} \mathrm{O}\right)_{x}$ afforded the chloro complexes $\mathbf{2 a}, \mathbf{2 b}, \mathbf{2 c}$ as yellow-orange microcrystalline solids in moderate yields as shown in Fig. 1. These complexes were readily crystallized from a mixture of $\mathrm{CH}_{3} \mathrm{OH}-\mathrm{CHCl}_{3}(1: 1)$ at $-30{ }^{\circ} \mathrm{C}$, which were then analyzed by $\mathrm{X}$-ray crystallography (see supporting information for the metric parameters for complexes $\mathbf{2 a - 2} \mathbf{c} \dagger$ ). The geometry around the $\mathrm{Rh}$ center for all three complexes can be described as a distorted octahedral and the ORTEP drawing of the molecular structures of $\mathbf{2 a}, \mathbf{2} \mathbf{b}$, and $\mathbf{2} \mathbf{c}$ are presented in Fig. 2. As can be seen the tetradentate $\mathrm{NN}^{\prime} \mathrm{O}_{2}$ spectator ligands enforce a meridional geometry in these complexes that afford the
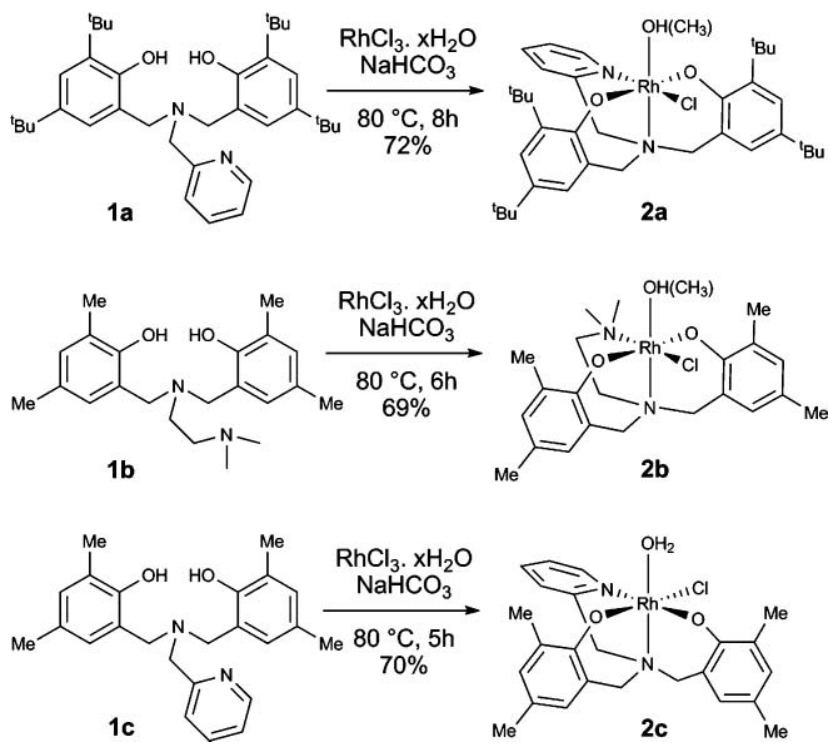

Fig. 1 Synthesis of the complexes $\mathbf{2 a - 2 c}$. 

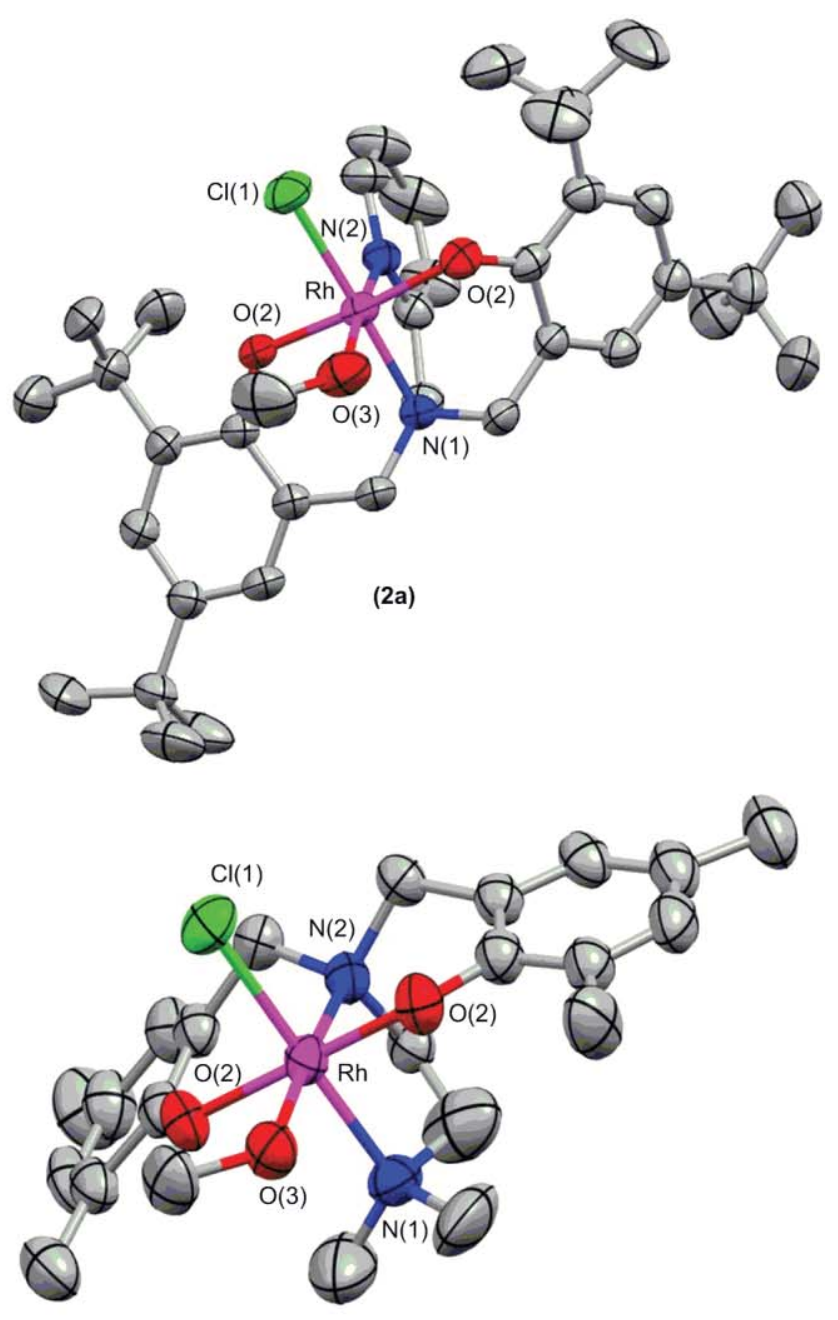

(2b)

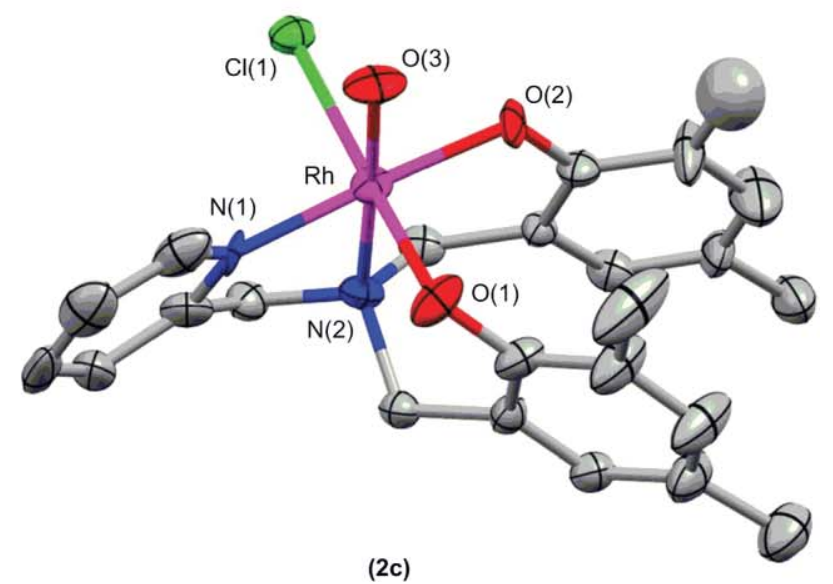

Fig. 2 ORTEP representation (50\% probability level) of the molecular structure of complexes 2a-2c. Solvent molecules as well as hydrogen atoms were omitted for clarity.

required $c i s$-geometry for the other two sites where reaction could occur.

The structures for $\mathbf{2 a}, \mathbf{2 b}$, and $\mathbf{2} \mathbf{c}$ in the solid state are consistent with solution NMR data with a trans-O,O for $\mathbf{2 a}$, with trans- bond angles $\mathrm{O}(1)-\mathrm{Rh}(1)-\mathrm{O}(2), \mathrm{O}(3)-\mathrm{Rh}(1)-\mathrm{N}(2)$, and $\mathrm{Cl}(1)-$ $\mathrm{Rh}(1)-\mathrm{N}(1)$ of 176.08(9), 174.89(11), and 178.26(8) respectively, trans-O,O for $\mathbf{2 b}$, with trans-bond angles $\mathrm{O}(1)-\mathrm{Rh}(1)-\mathrm{O}(2), \mathrm{O}(3)-$ $\mathrm{Rh}(1)-\mathrm{N}(1)$, and $\mathrm{Cl}(1)-\mathrm{Rh}(1)-\mathrm{N}(2)$ of 170.68(13), 176.73(14), and 178.75(13) respectively, and cis-O,O for 2c with trans-bond angles $\mathrm{O}(1)-\mathrm{Rh}(1)-\mathrm{Cl}(1), \mathrm{O}(3)-\mathrm{Rh}(1)-\mathrm{N}(2)$, and $\mathrm{O}(2)-\mathrm{Rh}(1)-\mathrm{N}(1)$ of 174.26(17), 177.1(2), and 175.4(2) respectively.

The selective trans-O,O in $\mathbf{2 a}$ and cis-O,O in $\mathbf{2} \mathbf{c}$ may be attributed to the subtle steric bulk between the two tert-butyl substituents in 2a. Similar selectivity in geometry is consistent with the observations made by Mountford and coworkers for the corresponding $\mathrm{Zr}\left(\mathrm{N}^{\mathrm{py}} \mathrm{N}^{\prime} \mathrm{O}_{2}{ }^{\mathrm{tBu}}\right) \mathrm{Cl}_{2}$ \{trans-O,O\}, and $\mathrm{Zr}\left(\mathrm{N}^{\mathrm{py}} \mathrm{N}^{\prime} \mathrm{O}_{2}{ }^{\mathrm{Me}}\right) \mathrm{Cl}_{2}$ $\{$ cis-O,O $\} .{ }^{7}$ However, it is not a priori obvious why complex $\mathbf{2 b}$ also favours trans-O,O. Consequently, we turned to DFT calculations (B3LYP/LACVP** using Jaguar 6.5 program suite, see supporting information for more information $\dagger)$. DFT calculations on the complexes cis/trans-2a indicate that the trans-2a $\left(0.0 \mathrm{kcal} \mathrm{mol}^{-1}\right)$ is favored over cis-2a $\left(3.4 \mathrm{kcal} \mathrm{mol}^{-1}\right)$. Similarly, trans-2b $(0.0 \mathrm{kcal}$ $\left.\mathrm{mol}^{-1}\right)$ is favored over $c i s-\mathbf{2 b}\left(2.8 \mathrm{kcal} \mathrm{mol}^{-1}\right)$ and $c i s-\mathbf{2 c}(0.0 \mathrm{kcal}$ $\left.\mathrm{mol}^{-1}\right)$ is favored over trans-2c $\left(1.5 \mathrm{kcal} \mathrm{mol}^{-1}\right)$. Since the cis-trans isomers are only separated by a couple $\mathrm{kcal} \mathrm{mol}^{-1}$ in solution, if the barrier to rearrange is manageable, both would be accessible during catalysis.

Moreover, as expected, the calculations suggest that the methyl analogues $\mathbf{2 b}$ and $\mathbf{2 c}$ do not show any preferences on the basis of sterics in either cis or trans-O,O coordination. However, trans2c exhibits substantial angle strain in the $\mathrm{Rh}-\mathrm{N}-\mathrm{CH}_{2}-\mathrm{C}=\mathrm{N}-\mathrm{Rh}$ metallacycle, as the coordination of the two phenolates trans to each other "push" the metallacycle into a planar configuration. This is not a problem in trans-2b, with a more flexible side arm as compared to complex $\mathbf{2 c}$.

Thus, we can conclude that electronically, the trans-O,O coordination is favored by $3 \mathrm{kcal} \mathrm{mol}^{-1}$. Making the $\mathrm{N}-\mathrm{C}-$ $\mathrm{C}-\mathrm{N}$ bridge more rigid increases the energy of the trans-O,O coordination, causing $c i s-\mathbf{2}$ to be favored, while the introduction of sterics on the phenolates increases the energy of the cis$\mathrm{O}, \mathrm{O}$ coordination, thus favoring the trans-O,O coordination in $2 \mathbf{a}$.

The Rh-N(1) distances vary from 2.019(7) to 2.040(2) $\AA$ in this set of compounds. While, the Rh-N(2) distances vary over much of this range for this series, 1.958(6) to 2.095(4) $\AA$. In addition, the $\mathrm{Rh}-\mathrm{O}$ distances vary together and are the same within error in complexes $\mathbf{2 a - 2 c}$. The $\mathrm{Rh}-\mathrm{Cl}$ distances are particularly sensitive to changes in ligands on $\mathrm{Rh}$ and, vary from 2.3475(13) to 2.3757(9) ^.

We were particularly interested in preparing $\mathrm{Rh}-\mathrm{Ar}$ derivatives because of their importance as catalysts for $\mathrm{C}-\mathrm{H}$ activation. Consequently, reaction of $2 \mathrm{c}$ with $\mathrm{Ph}_{2} \mathrm{Hg}$ in $\mathrm{CH}_{2} \mathrm{Cl}_{2}-\mathrm{CH}_{3} \mathrm{OH}$ (2:1) at room temperature afforded complex $\mathbf{3}$ as a yelloworange powder in $60 \%$ yield. $\mathrm{PhLi}, \mathrm{Ph}_{2} \mathrm{Zn}$ and $\mathrm{PhMgBr}$ afforded complex reaction mixtures. Crystallization from $\mathrm{CH}_{2} \mathrm{Cl}_{2}-$ hexane $(1: 1)$ yielded microcrystals of $\mathbf{3}$, which were analyzed by X-ray crystallography. The ORTEP drawing of the molecular structure of $\mathbf{3}$ is presented in Fig. 3. The solution NMR data and the solid state structure for $\mathbf{3}$ closely resembles $\mathbf{2 c}$, with the only notable difference being the expected replacement of the chloride with a phenyl group. The trans-bond angles $\mathrm{O}(1)-\mathrm{Rh}(1)-\mathrm{N}(2), \mathrm{O}(2)-\mathrm{Rh}(1)-\mathrm{C}(25)$, and $\mathrm{O}(3)-\mathrm{Rh}(1)-\mathrm{N}(1)$ are 175.6(3), 173.2(3), and 177.2(3) respectively. The $\mathrm{Rh}(1)-\mathrm{C}(25)$ 
Table 1 Comparison of the bond lengths ( $\AA$ ) of different Rh(III)$\mathrm{C}$ (phenyl) bonds in the crystal structures of $\mathbf{3}$ and analogous complexes

\begin{tabular}{lll}
\hline Complex & $\mathrm{Rh}-\mathrm{C}($ phenyl $)$ & Ref. \\
\hline $\mathrm{Rh}\left(\mathrm{N}^{\mathrm{py}} \mathrm{N}^{\prime} \mathrm{O}_{2}{ }^{\mathrm{Me}}\right)\left(\mathrm{CH}_{3} \mathrm{OH}\right)(\mathrm{Ph})(3)$ & $2.037(9)$ & This work \\
$\mathrm{Rh}\left(\mathrm{acac}^{\mathrm{a}} \mathrm{O}, \mathrm{O}\right)_{2}\left(\mathrm{CH}_{3} \mathrm{OH}\right)(\mathrm{Ph})$ & $1.970(3)$ & 8 \\
$\mathrm{Rh}(\mathrm{PNP})(\mathrm{Ph})(\mathrm{Br})$ & $2.005(6)$ & 9 \\
$\mathrm{RhCp}\left(\mathrm{C}(\mathrm{O})\left(\mathrm{CH}_{2}\right)_{2} \mathrm{SiMe}_{3}\right)\left(\mathrm{PMe}_{3}\right)(\mathrm{Ph})$ & $2.0636(12)$ & 10 \\
$\mathrm{RhCp}^{*}(\mathrm{PMe})(\mathrm{Ph})(\mathrm{Br})$ & $2.054(9)$ & 11 \\
$\mathrm{RhCp}^{*}\left(\mathrm{PMe}_{2} \mathrm{Ph}\right)(\mathrm{Ph})(\mathrm{Br})$ & $2.082(6)$ & 12 \\
$\mathrm{RhCp}^{*}\left(\mathrm{PMePh}_{2}\right)(\mathrm{Ph})(\mathrm{Br})$ & $2.065(5)$ & 12 \\
$\mathrm{RhCp}^{*}\left(\mathrm{PPh}_{3}\right)(\mathrm{Ph})(\mathrm{Br})$ & $2.08(1)$ & 12 \\
{$\left[\mathrm{RhCp}^{*}\left(\mathrm{PMe}_{3}\right)(\mathrm{Ph})\left(\mathrm{CH}_{2} \mathrm{Cl}_{2}\right)\right]\left[\mathrm{BAr}_{4}^{\prime}\right]$} & $2.026(8)$ & 13 \\
\hline
\end{tabular}
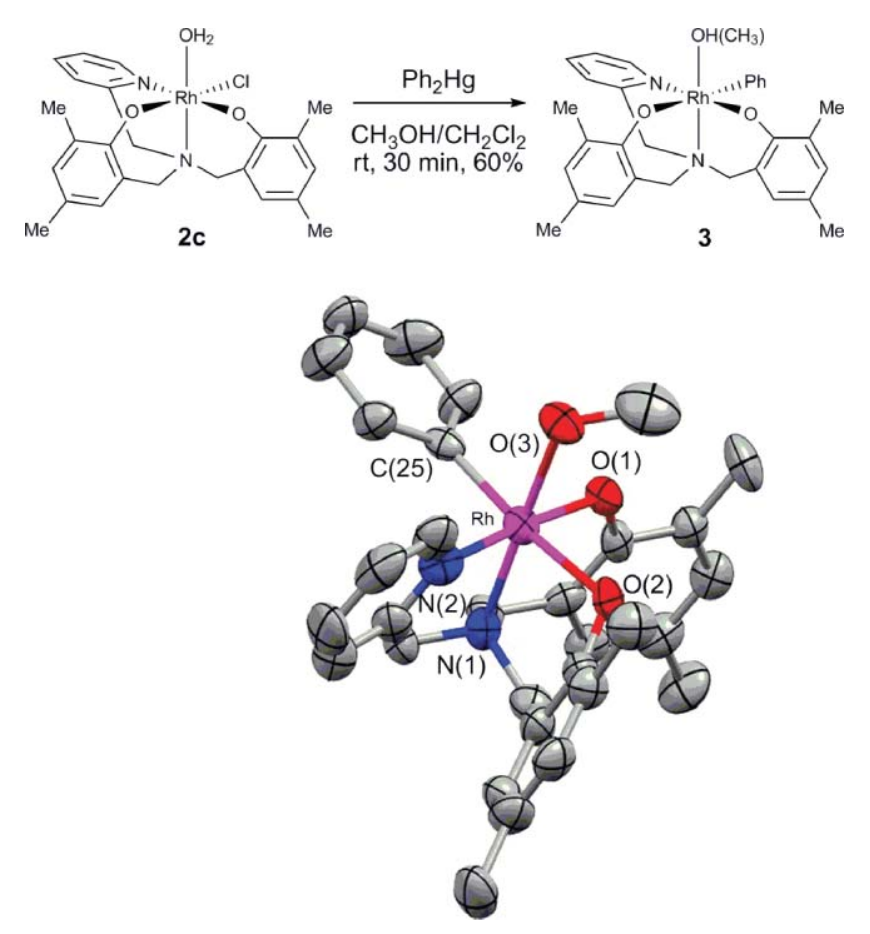

Fig. 3 Synthesis of complex 3 and ORTEP representation (50\% probability level) of the molecular structure of complex $\mathbf{3}$. Solvent molecules as well as hydrogen atoms were omitted for clarity.

bond length 2.037(9) is slightly longer than $1.970(3)$ to the analogous $\mathrm{CH}_{3} \mathrm{OH}$ adduct (acac-O,O $)_{2} \mathrm{Rh}(\mathrm{Ph})\left(\mathrm{CH}_{3} \mathrm{OH}\right)$ reported by our group. ${ }^{8}$ This $\mathrm{Rh}-$ (phenyl) bond distance is intermediate to the distances reported for the other published Rh(III) complexes (Table 1).

As expected on the basis of analogues studies with the chloro acac-O,O Ir(III) complexes, (acac-O,O $)_{2} \operatorname{Ir}(\mathrm{L}) \mathrm{Cl}$, the chloro complexes $2 \mathbf{a}-\mathbf{2 c}$, were found to be inactive for $\mathrm{C}-\mathrm{H}$ activation and decompose at temperatures above $160{ }^{\circ} \mathrm{C}$. However, the phenyl analogue of the chloro complex $\mathbf{2 c}$, complex $\mathbf{3}$, was found to catalyze H/D scrambling of a $\mathrm{C}_{6} \mathrm{H}_{6} / \mathrm{C}_{6} \mathrm{D}_{6}$ mixture. Computational and experimental studies of the reaction mechanisms, activation barriers and efforts to design complexes for $\mathrm{C}-\mathrm{H}$ activation with alternative ancillary ligands are in progress.

\section{Conclusions}

In summary we have reported a series of $\mathrm{Rh}\left(\mathrm{NN}^{\prime} \mathrm{O}_{2}\right)$ complexes. The $\mathrm{NN}^{\prime} \mathrm{O}_{2}$ ligand framework is readily accessed and has proven useful in $\mathrm{C}-\mathrm{H}$ activation reactions. A variety of rhodium complexes are synthesized with this tetradentate ancillary ligand. Unlike complex 3, the isolated complexes $\mathbf{2 a}-\mathbf{2} \mathbf{c}$ are inactive for $\mathrm{C}-\mathrm{H}$ activation. It is hoped that these complexes and derivatives may provide a new, general class of reactive complexes for $\mathrm{C}-\mathrm{H}$ activation.

\section{Experimental}

\section{General considerations}

All manipulations of air sensitive materials were carried out in an MBraun glove box or using standard Schlenk techniques under an atmosphere of purified argon. Ethereal solvents, pentane, and toluene were purchased from Aldrich Chemical Co. or EMD and purified through alumina columns to remove water after sparging with argon to remove oxygen. NMR solvents were purchased from Cambridge Isotopes Laboratories, Inc. and degassed prior to use. NMR spectra were taken on Bruker instruments located in the Chemistry Department at The Scripps Research Institute, Florida. All chemical shifts are reported in units of ppm and referenced to the residual protonated solvent. The ${ }^{13} \mathrm{C}$ NMR assignments are based on decoupled ${ }^{13} \mathrm{C}$, peak heights for overlapping signals, and DEPT experiments. All spectra were recorded at $23{ }^{\circ} \mathrm{C}$. Combustion analyses were performed by facilities at Columbia Analytical Services, Tucson, Arizona. Multiple runs for the elemental analysis of complexes $\mathbf{2 a}, \mathbf{2} \mathbf{c}$ and $\mathbf{3}$ did not afford reliable results, due to relatively labile solvent ligands. ESI-MS experiments were performed by facilities at the University of Illinois. Celite was dried at a temperature $>220^{\circ} \mathrm{C}$ under dynamic vacuum for at least $24 \mathrm{~h}$, then stored under argon. $\mathrm{RhCl}_{3} \cdot\left(\mathrm{H}_{2} \mathrm{O}\right)_{3}$ was purchased from Pressure Chemical Co. and used without purification. All highresolution mass spectra were obtained by UCLA Pasarow Mass Spectrometry Laboratory on either an ESI or a MALDI-TOF mass spectrometer.

Synthesis of $\mathbf{R h}\left(\mathrm{N}^{\mathrm{py}} \mathbf{N}^{\prime} \mathbf{O}_{2}{ }^{\mathrm{tBu}}\right)(\mathbf{C l})\left(\mathrm{CH}_{3} \mathbf{O H}\right)$ (2a). A $50 \mathrm{~mL}$ Schlenk bomb was loaded with $\mathrm{RhCl}_{3} \cdot\left(\mathrm{H}_{2} \mathrm{O}\right)_{3}(230 \mathrm{mg}, 0.89 \mathrm{mmol})$ in water $(5 \mathrm{~mL})$. To this was added a solution of $\mathrm{H}_{2} \mathrm{~N}^{\text {py }} \mathrm{N}^{\prime} \mathrm{O}_{2}{ }^{\text {tBu }}$ (485 mg, $0.89 \mathrm{mmol}, 1$ equiv.) in acetone $(10 \mathrm{~mL})$. The reaction mixture was heated at $80^{\circ} \mathrm{C}$ for $5 \mathrm{~min}$ to afford a homogeneous orange solution. After $5 \mathrm{~min}, \mathrm{NaHCO}_{3}(150 \mathrm{mg}, 1.78 \mathrm{mmol})$ was added to the reaction mixture and the mixture heated at $80{ }^{\circ} \mathrm{C}$ for $8 \mathrm{~h}$. After $8 \mathrm{~h}$, the reaction mixture was filtered through Celite, and the volatiles were removed in vacuo. The desired product was crystallized from a minimum amount of $\mathrm{CH}_{3} \mathrm{OH}-\mathrm{CH}_{2} \mathrm{Cl}_{2}(1: 1)$ at $-30{ }^{\circ} \mathrm{C}$ as light orange micro-crystals $(414 \mathrm{mg}, \mathrm{mmol}, 72 \%)$. The NMR spectroscopic data are consistent with trans-isomer in $\mathrm{CDCl}_{3}: \mathrm{CH}_{3} \mathrm{OH} .{ }^{1} \mathrm{H}$ NMR $\left(400 \mathrm{MHz}, \mathrm{CD}_{3} \mathrm{OD} / \mathrm{CDCl}_{3}, 1: 1\right)$ : $9.41\left(\mathrm{~d}, J_{\mathrm{HH}}=6 \mathrm{~Hz}, 1 \mathrm{H}, \mathrm{Py}\right), 7.41\left(\mathrm{t}, J_{\mathrm{HH}}=7.5 \mathrm{~Hz}, 1 \mathrm{H}, \mathrm{Py}\right), 7.00$ $\left(\mathrm{t}, J_{\mathrm{Hн}}=7 \mathrm{~Hz}, 1 \mathrm{H}, \mathrm{Py}\right), 6.90\left(\mathrm{~d}, J_{\mathrm{Hн}}=3 \mathrm{~Hz}, 2 \mathrm{H}, \mathrm{Ar}\right), 6.87(\mathrm{~d}$, $\left.J_{\mathrm{HH}}=3 \mathrm{~Hz}, 2 \mathrm{H}, \mathrm{Ar}\right), 6.75\left(\mathrm{~d}, J_{\mathrm{HH}}=8 \mathrm{~Hz}, 1 \mathrm{H}, \mathrm{Py}\right), 4.90\left(\mathrm{~d}, J_{\mathrm{HH}}=\right.$ $\left.13 \mathrm{~Hz}, 2 \mathrm{H}, \mathrm{CHAr}, \mathrm{CHAr}^{\prime}\right), 4.29\left(\mathrm{~s}, 2 \mathrm{H}, \mathrm{CH}_{2} \mathrm{Py}\right), 3.53\left(\mathrm{~d}, J_{\mathrm{HH}}=\right.$ $13 \mathrm{~Hz}, 2 \mathrm{H}, \mathrm{CHAr}, \mathrm{CHAr}), 1.22$ (s, $18 \mathrm{H}, \mathrm{t}-\mathrm{Bu}$ ), 1.19 (s, $18 \mathrm{H}, \mathrm{t}-$ $\mathrm{Bu}) .{ }^{13} \mathrm{C}\left\{{ }^{1} \mathrm{H}\right\}$ NMR $\left(\mathrm{CD}_{3} \mathrm{OD} / \mathrm{CDCl}_{3}\right): 157.1,154.1,148.7,141.4$, $138.1,136.9,125.8,124.4,123.95,123.2,122.3,57.4,56.3,35.6$, $34.7,32.1,30.10$.

Synthesis of $\mathbf{R h}\left(\mathrm{N}^{\mathrm{NMe} 2} \mathrm{~N}^{\prime} \mathrm{O}_{2}{ }^{\mathrm{Me}}\right)\left(\mathrm{Cl}_{(1}\left(\mathrm{CH}_{3} \mathrm{OH}\right)(\mathbf{2 b})\right.$. A $50 \mathrm{~mL}$ Schlenk bomb was loaded with $\mathrm{RhCl}_{3} \cdot\left(\mathrm{H}_{2} \mathrm{O}\right)_{3}(306 \mathrm{mg}, 1.19 \mathrm{mmol})$ 
in water $(5 \mathrm{~mL})$. To this was added a solution of $\mathrm{H}_{2} \mathrm{~N}^{\mathrm{NMe} 2} \mathrm{~N}^{\prime} \mathrm{O}_{2}{ }^{\mathrm{Me}}$ (423 mg, $1.19 \mathrm{mmol}, 1$ equiv.) in acetone $(10 \mathrm{~mL})$. The reaction mixture was heated at $80{ }^{\circ} \mathrm{C}$ for 5 min to afford a homogeneous orange solution. After $5 \mathrm{~min}, \mathrm{NaHCO}_{3}(200 \mathrm{mg}, 2.38 \mathrm{mmol})$ was added to the reaction mixture and the mixture heated at $80{ }^{\circ} \mathrm{C}$ for $6 \mathrm{~h}$. After $6 \mathrm{~h}$, the reaction mixture was filtered through Celite, and the volatiles were removed in vacuo. The desired product was crystallized from a minimum amount of $\mathrm{CH}_{3} \mathrm{OH}-\mathrm{CH}_{2} \mathrm{Cl}_{2}(1: 1)$ at $-30{ }^{\circ} \mathrm{C}$ as orange-red micro-crystals (420 mg, mmol, 69\%). The NMR spectroscopic data are consistent with trans-isomer in $\mathrm{CDCl}_{3}: \mathrm{CH}_{3} \mathrm{OH} .{ }^{1} \mathrm{H} \mathrm{NMR}\left(\mathrm{CD}_{3} \mathrm{OD} / \mathrm{CDCl}_{3}, 1: 1\right): 6.78$ (d, $\left.J_{\mathrm{HH}}=2 \mathrm{~Hz}, 2 \mathrm{H}, \mathrm{Ar}\right), 6.65\left(\mathrm{~d}, J_{\mathrm{HH}}=2 \mathrm{~Hz}, 2 \mathrm{H}, \mathrm{Ar}\right), 5.39(\mathrm{~d}$, $\left.J_{\mathrm{HH}}=13 \mathrm{~Hz}, 2 \mathrm{H}, \mathrm{CHAr}, \mathrm{CHAr}^{\prime}\right), 3.26\left(\mathrm{~d}, J_{\mathrm{HH}}=13 \mathrm{~Hz}, 2 \mathrm{H}\right.$, CHAr, CHAr'), $2.84\left(\mathrm{t}, J_{\mathrm{HH}}=6 \mathrm{~Hz}, 2 \mathrm{H}, \mathrm{CH}_{2} \mathrm{~N}\right), 2.17(\mathrm{~s}, 6 \mathrm{H}$, $\mathrm{Me}), 2.15(\mathrm{~s}, 6 \mathrm{H}, \mathrm{Me}), 2.13(\mathrm{~s}, 6 \mathrm{H}, \mathrm{Me}), 2.06\left(\mathrm{t}, J_{\mathrm{HH}}=6 \mathrm{~Hz}\right.$, $\left.2 \mathrm{H}, \mathrm{CH}_{2} \mathrm{~N}\right) \cdot{ }^{13} \mathrm{C}\left\{{ }^{1} \mathrm{H}\right\} \mathrm{NMR}\left(\mathrm{CD}_{3} \mathrm{OD} / \mathrm{CDCl}_{3}\right): 161.1,133.1,129.8$, 128.6, 124.1, 121.0, 67.3, 64.7, 57.5, 50.3, 20.4, 17.7. Anal. Calcd for $\mathrm{C}_{22} \mathrm{H}_{32} \mathrm{ClN}_{2} \mathrm{O}_{3} \mathrm{Rh}\left(\mathrm{H}_{2} \mathrm{O}\right)$ : C, 50.79; H, 6.86; Cl, 6.52; N, 5.15. Found: C, 50.86; H, 6.29; Cl, 6.53; N, 5.45. ESI-MS Calculated for $\mathrm{C}_{23} \mathrm{H}_{34} \mathrm{ClN}_{2} \mathrm{O}_{3} \mathrm{Rh}(\mathrm{M})^{+}$: 524.1313 Found 524.1308.

Synthesis of $\mathbf{R h}\left(\mathbf{N}^{\mathrm{py}} \mathbf{N}^{\prime} \mathbf{O}_{2}{ }^{\mathrm{Me}}\right)(\mathbf{C l})\left(\mathbf{H}_{2} \mathbf{O}\right)(\mathbf{2 c})$. A $50 \mathrm{~mL}$ Schlenk bomb was loaded with $\mathrm{RhCl}_{3} \cdot\left(\mathrm{H}_{2} \mathrm{O}\right)_{3}(250 \mathrm{mg}, 0.97 \mathrm{mmol})$ in water $(5 \mathrm{~mL})$. To this was added a solution of $\mathrm{H}_{2} \mathrm{~N}^{\mathrm{py}} \mathrm{N}^{\prime} \mathrm{O}_{2}{ }^{\mathrm{Me}}(365 \mathrm{mg}$, $0.97 \mathrm{mmol}, 1$ equiv.) in acetone $(10 \mathrm{~mL})$. The reaction mixture was heated at $80{ }^{\circ} \mathrm{C}$ for $5 \mathrm{~min}$ to afford a homogeneous orange solution. After $5 \mathrm{~min}, \mathrm{NaHCO}_{3}(163 \mathrm{mg}, 1.94 \mathrm{mmol})$ was added to the reaction mixture and the mixture heated at $80{ }^{\circ} \mathrm{C}$ for $5 \mathrm{~h}$. After $5 \mathrm{~h}$, the reaction mixture was filtered through Celite, and the volatiles were removed in vacuo. The desired product was crystallized from a minimum amount of $\mathrm{CH}_{3} \mathrm{OH}-\mathrm{CH}_{2} \mathrm{Cl}_{2}(1: 1)$ at $-30{ }^{\circ} \mathrm{C}$ as bright orange micro-crystals (360 mg, mmol, $70 \%$ ). The $\mathrm{NMR}$ spectroscopic data are consistent with cis-isomer in $\mathrm{CDCl}_{3}$ : $\mathrm{CH}_{3} \mathrm{OH} .{ }^{1} \mathrm{H}$ NMR (400 MHz, $\left.\mathrm{CD}_{3} \mathrm{OD} / \mathrm{CDCl}_{3}, 1: 1\right): 8.50$ (d, $\left.J_{\mathrm{HH}}=5.5 \mathrm{~Hz}, 1 \mathrm{H}, \mathrm{Py}\right), 7.59\left(\mathrm{t}, J_{\mathrm{HH}}=6 \mathrm{~Hz}, 1 \mathrm{H}, \mathrm{Py}\right), 7.13(\mathrm{~m}, 2 \mathrm{H}$, Py), 6.79 (s, 1H, Ar), 6.70 (s, 1H, Ar), 6.41 (s, 1H, Ar), 6.35 (s, 1H, Ar), $5.53\left(\mathrm{~d}, J_{\mathrm{HH}}=13 \mathrm{~Hz}, 1 \mathrm{H}, \mathrm{CHAr}\right), 4.98\left(\mathrm{~d}, J_{\mathrm{HH}}=15 \mathrm{~Hz}, 1 \mathrm{H}\right.$, CHAr), 4.19 (d, $\left.J_{\mathrm{HH}}=15 \mathrm{~Hz}, 1 \mathrm{H}, \mathrm{CHPy}\right), 3.77\left(\mathrm{~d}, J_{\mathrm{HH}}=13 \mathrm{~Hz}\right.$, $1 \mathrm{H}, \mathrm{CHPy}), 3.53\left(\mathrm{~d}, J_{\mathrm{HH}}=13 \mathrm{~Hz}, 1 \mathrm{H}, \mathrm{CHAr}\right), 2.75\left(\mathrm{~d}, J_{\mathrm{HH}}=13 \mathrm{~Hz}\right.$, 1H, CHAr), 2.33 (s, 3H, Me), 2.15 (s, 3H, Me), 2.00 (s, 3H, Me), $1.85(\mathrm{~s}, 3 \mathrm{H}, \mathrm{Me}) \cdot{ }^{13} \mathrm{C}\left\{{ }^{1} \mathrm{H}\right\} \mathrm{NMR}\left(\mathrm{CD}_{3} \mathrm{OD} / \mathrm{CDCl}_{3}\right)$ : 163.0, 149.6, $149.5,139.5,132.7,132.6,130.1,129.4,128.8,128.3,127.0,126.5$, 124.1, 123.9, 122.1, 121.8, 69.7, 66.8, 61.8, 20.50, 20.46, 18.1, 17.2. ESI-MS Calculated for $\mathrm{C}_{24} \mathrm{H}_{27} \mathrm{ClN}_{2} \mathrm{O}_{2} \mathrm{Rh}(\mathrm{M}-\mathrm{OH})^{+}: 513.0843$ Found 513.0809.

Synthesis of $\mathbf{R h}\left(\mathbf{N}^{\mathrm{py}} \mathbf{N}^{\prime} \mathbf{O}_{2}{ }^{\mathrm{Me}}\right)(\mathbf{P h})\left(\mathrm{CH}_{3} \mathbf{O H}\right)$ (3). A $50 \mathrm{~mL}$ Schlenk bomb was loaded with 2c (100 mg, $0.184 \mathrm{mmol})$ in $\mathrm{CH}_{2} \mathrm{Cl}_{2}-\mathrm{CH}_{3} \mathrm{OH}(2: 1)$ (30 mL). To this was added $\mathrm{Ph}_{2} \mathrm{Hg}(72 \mathrm{mg}$, $0.202 \mathrm{mmol}$ ) (Caution! $\mathrm{Ph}_{2} \mathrm{Hg}$ is extremely toxic) as a solid. The reaction mixture was stirred vigorously for $30 \mathrm{~min}$. After $30 \mathrm{~min}$, the reaction mixture was filtered through Celite, and the volatiles were removed in vacuo. The desired product was crystallized from a minimum amount of $\mathrm{CH}_{3} \mathrm{OH}-\mathrm{CH}_{2} \mathrm{Cl}_{2}(1: 1)$ at $-30{ }^{\circ} \mathrm{C}$ as orange micro-crystals (65 $\mathrm{mg}, \mathrm{mmol}, 60 \%$ ). The NMR spectroscopic data are consistent with cis-isomer in $\mathrm{CDCl}_{3}: \mathrm{CH}_{3} \mathrm{OH} .{ }^{1} \mathrm{H} \mathrm{NMR}$ $\left(\mathrm{CDCl}_{3} / \mathrm{CD}_{3} \mathrm{OD}, 1: 1\right): 8.34\left(\mathrm{br}, \mathrm{d}, J_{\mathrm{HH}}=6,1 \mathrm{H}, \mathrm{Py}\right), 7.51\left(\mathrm{t}, J_{\mathrm{HH}}=\right.$ $7.5,1 \mathrm{H}, \mathrm{Py}), 7.06\left(\mathrm{t}, J_{\mathrm{HH}}=6.5,2 \mathrm{H}, \mathrm{Py}\right), 6.84(\mathrm{~s}, 1 \mathrm{H}, \mathrm{Ar}), 6.81(\mathrm{~s}$,
5H, Ph), 6.55 (br, s, 1H, Ar), 6.24 (br, s, 2H, Ar), 4.59 (d, $J_{\mathrm{HH}}=$ $13,1 \mathrm{H}, \mathrm{CHN}), 4.17\left(\mathrm{~d}, J_{\mathrm{HH}}=12.5,1 \mathrm{H}, \mathrm{CHN}\right), 3.97\left(\mathrm{~d}, J_{\mathrm{HH}}=15\right.$, $1 \mathrm{H}, \mathrm{CHN}), 3.79\left(\mathrm{~d}, J_{\mathrm{HH}}=15,1 \mathrm{H}, \mathrm{CHN}\right), 3.18\left(\mathrm{~d}, J_{\mathrm{HH}}=13,1 \mathrm{H}\right.$, $\mathrm{CHN}), 2.55\left(\mathrm{~d}, J_{\mathrm{HH}}=12,1 \mathrm{H}, \mathrm{CHN}\right), 2.35$ (s, 3H, MeAr), 2.14 (s, $3 \mathrm{H}, \mathrm{MeAr}), 1.96$ (s, 6H, MeAr). ${ }^{13} \mathrm{C}\left\{{ }^{1} \mathrm{H}\right\} \mathrm{NMR}\left(\mathrm{CD}_{3} \mathrm{OD} / \mathrm{CDCl}_{3}\right)$ : 148.5, 137.5, 137.2, 133.0, 132.0, 129.0, 128.7, 127.7, 123.9, 123.7, $122.1,121.7,120.9,69.9,67.0,61.6,20.50,20.42$, 18.0, 17.1. ESIMS Calculated for $\mathrm{C}_{30} \mathrm{H}_{32} \mathrm{~N}_{2} \mathrm{O}_{2} \mathrm{Rh}\left(\mathrm{M}-\mathrm{OCH}_{3}\right)^{+}: 555.1519$ Found 555.1514 .

\section{Acknowledgements}

The authors thank Chevron Energy Technology Company, Center for Catalytic Hydrocarbon Functionalization, an Energy Frontier Research Center (DOE DE-SC000-1298) and Scripps Florida for financial Support. The facilities of the Materials and Process Simulation Center used for these studies were provided by DURIP-ARO and DURIP-ONR. The authors thank Muhammed Yousufuddin, Nam Nhat Ho, Irina Tsyba and Professor Bau for $\mathrm{X}$-ray diffraction studies. The authors also thank $\mathrm{Mu}$-Jeng Cheng, Robert J. Nielsen, and Richard J. Staples for helpful discussions.

\section{Notes and references}

1 For the preparation of (acac-O,O $)_{2} \operatorname{Ir}(\mathrm{R})(\mathrm{L})$ see: M. A. Bennett and T. R. B. Mitchell, Inorg. Chem., 1976, 15, 2936.

2 For the application of the complex to hydroarylation see: (a) T. Matsumoto, D. J. Taube, R. A. Periana, H. Taube and H. Yoshida, J. Am. Chem. Soc., 2000, 122, 7414; (b) S. M. Bischof, D. H. Ess, S. K. Meier, J. Oxgaard, R. J. Nielsen, G. Bhalla, W. A. Goddard III and R. A. Periana, Organometallics, 2010, 29, 742; (c) A. G. Wong-Foy, G. Bhalla, X. Y. Liu and R. A. Periana, J. Am. Chem. Soc., 2003, 125, 14292; (d) R. A. Periana, X. Y. Liu and G. Bhalla, Chem. Commun., 2002, 3000; (e) G. Bhalla, X. Y. Liu, J. Oxgaard, W. A. Goddard III and R. A. Periana, J. Am. Chem. Soc., 2005, 127, 11372; (f) G. Bhalla, J. Oxgaard, W. A. Goddard III and R. A. Periana, Organometallics, 2005, 24, 3229; ( $g$ ) W. J. Tenn, K. J. H. Young, J. Oxgaard, R. J. Nielsen, W. A. Goddard III and R. A. Periana, Organometallics, 2006, 25, 5173; (h) W. A. Tenn, K. J. H. Young, G. Bhalla, J. Oxgaard, W. A. Goddard III and R. A. Periana, J. Am. Chem. Soc., 2005, 127, 14172.

3 (a) J. Oxgaard, R. P. Muller, W. A. Goddard III and R. A. Periana, J. Am. Chem. Soc., 2004, 126, 352; (b) J. Oxgaard, G. Bhalla, R. A. Periana and W. A. Goddard III, Organometallics, 2006, 25, 1618; (c) J. Oxgaard, R. A. Periana and W. A. Goddard III, J. Am. Chem. Soc., 2004, 126, 11658.

4 E. Y. Tshuva, S. Groysman, I. Goldberg, M. Kol, H. Weitman and Z. Goldschmidt, Chem. Commun., 2000, 379.

5 S. Barroso, P. Adão, F. Madeira, M. T. Duarte, J. C. Pessoa and A. M. Martins, Inorg. Chem., 2010, 49, 7452.

6 E. Y. Tshuva, I. Goldberg and M. Kol, Organometallics, 2001, 20, 3017.

7 For more examples see: (a) $\mathrm{Zr}\left(\mathrm{NpyN}^{\prime} \mathrm{O}_{2} \mathrm{tBu}\right)(\mathrm{Cl})_{2}\{$ trans-O,O $\}:(a) \mathrm{T}$. Toupance, S. R. Dubberley, N. H. Rees, B. R. Tyrrell and P. Mountford, Organometallics, 2002, 21, 1367; (b) $\mathrm{Ti}\left(\mathrm{N}^{\mathrm{py}} \mathrm{N}^{\prime} \mathrm{O}_{2}{ }^{\mathrm{Me}}\right) \mathrm{Cl}_{2}\{$ cis-O,O $\}$ : C. L. Byod, T. Toupance, B. R. Tyrrell, B. D. Ward, C. R. Wilson, A. R. Cowley and P. Mountford, Organometallics, 2005, 24, 309.

8 X. Y. Liu, W. J. Tenn III, G. Bhalla and R. A. Periana, Organometallics, 2004, 23, 3584.

9 S. Gatard, R. Ç. Çetin, C. Guo, B. M. Foxman and O. V. Ozerov, J. Am. Chem. Soc., 2006, 128, 2808.

10 A. H. Roy, C. P. Lenges and M. Brookhart, J. Am. Chem. Soc., 2007, 129, 2082.

11 W. D. Jones and F. J. Feher, Inorg. Chem., 1984, 23, 2376.

12 W. D. Jones and V. L. Kuykendall, Inorg. Chem., 1991, 30, 2615.

13 B. K. Corkey, F. L. Taw, R. G. Bergman and M. Brookhart, Polyhedron, 2004, 23, 2943. 